\title{
Prognostic value of the long noncoding RNA HOTTIP in human cancers
}

\author{
Wei Li ${ }^{1}$, Na Li ${ }^{2}$, Xinmei Kang ${ }^{1}, \mathrm{Ke} \mathrm{Shi}^{1}$ and Qiong Chen ${ }^{1}$ \\ ${ }^{1}$ Department of Geriatrics, Xiangya Hospital of Central South University, Changsha, Hunan Province, People's Republic of China \\ ${ }^{2}$ Department of Pathology, The First Affiliated Hospital of Hunan University of Medicine, Huaihua, Hunan Province, People's \\ Republic of China
}

Correspondence to: Qiong Chen, email: qiongch@163.com

Ke Shi, email: csushike@163.com

Keywords: HOTTIP, IncRNA, cancer, clinical outcome, meta-analysis

Received: March 28, 2017 Accepted: June 28, $2017 \quad$ Published: July 11, 2017

Copyright: Li et al. This is an open-access article distributed under the terms of the Creative Commons Attribution License 3.0 (CC BY 3.0), which permits unrestricted use, distribution, and reproduction in any medium, provided the original author and source are credited.

\section{ABSTRACT}

Human Homeobox A transcript at the distal tip (HOTTIP) is a putative oncogene in solid tumors. We performed a meta-analysis to investigate the association between HOTTIP expression and clinical outcomes in cancer patients. Eligible studies were collected from a literature search of the online electronic databases of Embase, Web of Science, PubMed and the China National Knowledge Infrastructure (up to January 2 , 2017). Fixed-effects models were used to compute pooled odds ratios (ORs) and hazard ratios (HRs). In total, we analyzed nine studies that included 800 patients with seven tumor types. Overall survival was lower for patients with high HOTTIP expression than for those with low expression ( $H R=2.30,95 \%$ confidence interval [CI]: 1.81-2.91, $P<0.001)$. High HOTTIP expression was also associated with lymph node metastasis (OR $=2.40,95 \% \mathrm{CI}: 1.70-3.37, P<0.001)$, distant metastasis (OR = 3.30, 95\% CI: 1.78-6.12, $P<0.001)$, poor tumor differentiation $(O R=1.55$, 95\% CI: $1.03-2.32, P=0.036)$ and a poor clinical stage (OR $=3.28,95 \%$ CI: $2.22-4.83$, $P<0.001)$. This meta-analysis demonstrated that high HOTTIP expression in cancer patients is associated with poor clinical outcomes. Thus, HOTTIP is a potential predictive biomarker of cancer.

\section{INTRODUCTION}

Cancer is a major health problem all over the world, as the second leading and leading cause of death in the US and China, respectively $[1,2]$. Although diagnostic and treatment modalities have been developed for decades, the average five-year survival rate for cancer patients is still very low. The main reasons for the high cancer mortality rate are the lack of effective detection methods at early stages and the high recurrence rate. Therefore, the study of diagnostic and prognostic markers in cancer patients has major clinical significance.

Long noncoding RNAs (lncRNAs) are RNA molecules ranging from 200 nucleotides to 100 kilobases in length, without protein-coding abilities [3, 4]. LncRNAs are deregulated in a variety of diseases, including cancer [5-8]. These differentially expressed RNAs participate in various regular biological processes at the transcriptional and posttranscriptional levels [5]. LncRNAs can regulate gene expression through multiple approaches, such as by recruiting transcription factors or directly binding to proteins, RNA and DNA [5]. Many lncRNAs have been reported to participate in tumorigenesis, tumor progression and cancer prognosis [9-12].

Homeobox A transcript at the distal tip (HOTTIP) is a 3,764-nucleotide-long lncRNA encoded by a gene at the 5 ' end of the HOXA cluster (chromosome 7p15.2) [4]. HOTTIP is upregulated in various carcinomas, such as lung carcinoma [13], gastric carcinoma (GC) [9], pancreatic carcinoma [11], hepatocellular carcinoma (HCC) [8] and squamous cell carcinoma [14]. In addition, HOTTIP levels have been associated with tumor pathological characteristics and patient prognostic outcomes [10-14]. These findings suggest that HOTTIP could be developed as a potential diagnostic and prognostic biomarker for human cancers. However, individual studies may be inaccurate or inadequate due to limitations of the sample sizes or research programs. Therefore, in this study, we collected 
all relevant publications and conducted a meta-analysis to explore the relationship between HOTTIP expression and cancer clinical outcomes, and to determine the potential of HOTTIP as a common predictive biomarker for metastasis and prognosis in cancer patients.

\section{RESULTS}

\section{Study characteristics}

Our initial search retrieved 327 potentially relevant papers from Embase, Web of Science, PubMed and the China National Knowledge Infrastructure (CNKI). Following the removal of duplicates, 290 records were preserved. After the titles and abstracts were screened, 39 full-text articles remained. However, 30 of them were excluded due to incomplete data. Ultimately, nine studies met the eligibility criteria and were included in the metaanalysis [8-12, 13, 15-17]. A flow diagram of the study selection process is shown in Figure 1.

In total, 800 patients were included in this study. Eight studies came from China and one came from Switzerland. Cancers of seven carcinoma types were included in our study: HCC, osteosarcoma (OSA), colorectal cancer (CRC), pancreatic cancer (PC), GC, tongue squamous cell carcinoma (TSCC) and breast cancer (BC). In all of the studies, lncRNA HOTTIP expression was detected by quantitative reverse transcription PCR (qRT-PCR). The main features of the nine studies that qualified for the present meta-analysis are summarized in Table 1 .

\section{Relationship between increased HOTTIP expression and overall survival}

The relationship between HOTTIP expression and overall survival (OS) was evaluated in eight studies including 752 patients. No significant heterogeneity was observed among the studies $\left(I^{2}=0 \%, P=0.922\right)$, so a fixed-effects model was used to pool the results. The pooled HR indicated that HOTTIP expression was negatively associated with OS $(\mathrm{HR}=2.30,95 \%$ confidence interval $[\mathrm{CI}]: 1.81-2.91$, $P<0.001$, fixed-effects model) (Figure 2). To evaluate the robustness of the merged results, we conducted a sensitivity analysis by successively omitting each individual study. The results were not significantly affected by the exclusion of any individual study, indicating that the results of this meta-analysis were robust (Figure 3).
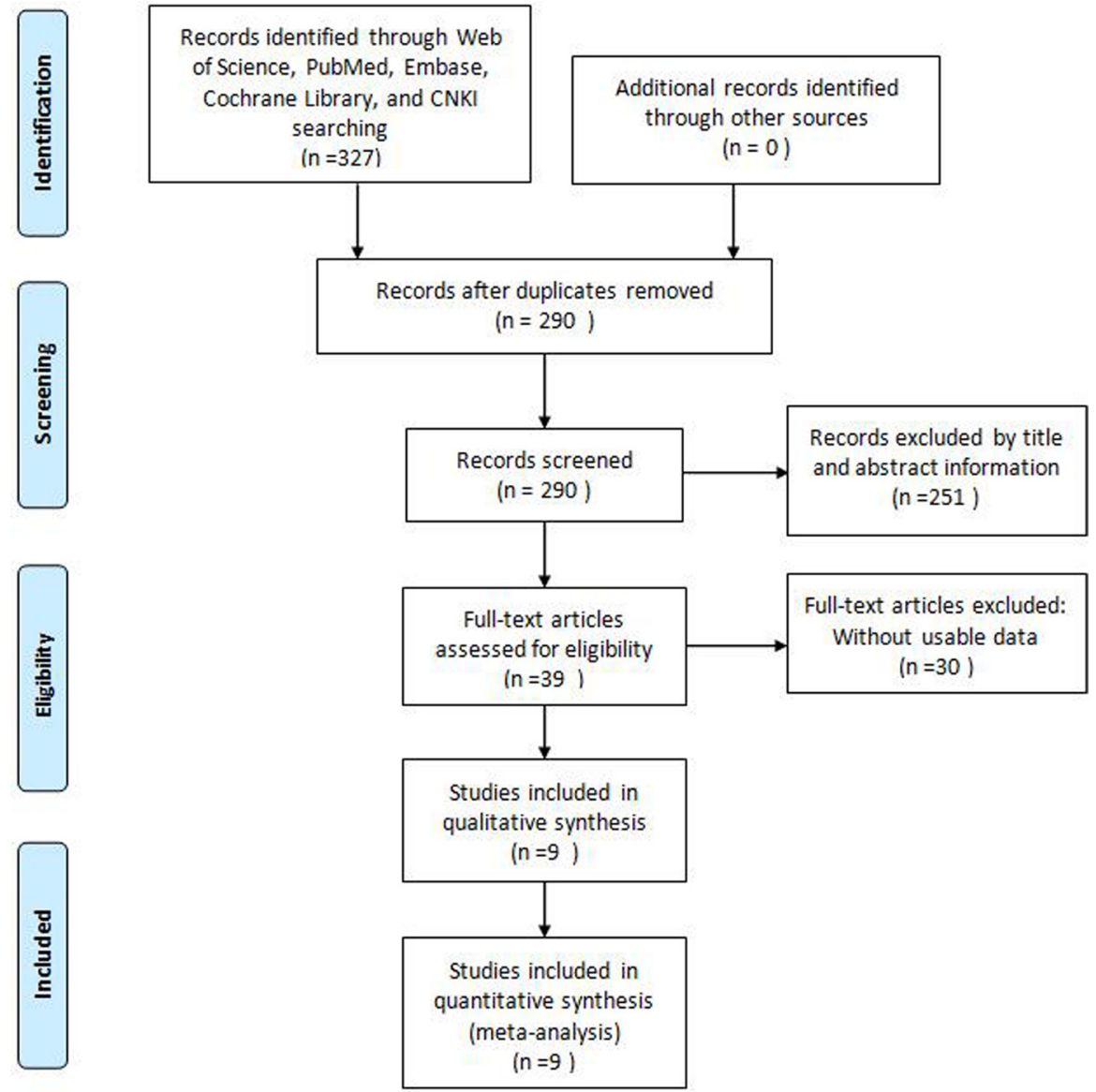

Figure 1: Flow diagram of the literature search and selection. 
Table 1: Main characteristic of the eligible studies

\begin{tabular}{|c|c|c|c|c|c|c|c|c|c|c|c|c|c|}
\hline \multirow[b]{2}{*}{ Study } & \multirow[b]{2}{*}{ Region } & \multirow[b]{2}{*}{$\begin{array}{c}\text { Tumor } \\
\text { type }\end{array}$} & \multirow[b]{2}{*}{$\begin{array}{l}\text { Sample } \\
\text { size }\end{array}$} & \multirow[b]{2}{*}{$\begin{array}{c}\text { Test } \\
\text { method }\end{array}$} & \multirow[b]{2}{*}{ Cut-off } & \multicolumn{6}{|c|}{ HOTTIP expression } & \multirow[b]{2}{*}{$\begin{array}{c}\text { Outcome } \\
\text { measure }\end{array}$} & \multirow[b]{2}{*}{$\begin{array}{c}\text { Follow-up } \\
\text { (months) }\end{array}$} \\
\hline & & & & & & $\begin{array}{c}\text { High } \\
\text { with } \\
\text { LNM }\end{array}$ & $\begin{array}{l}\text { High } \\
\text { with } \\
\text { DM }\end{array}$ & High & $\begin{array}{c}\text { Low } \\
\text { with } \\
\text { LNM }\end{array}$ & $\begin{array}{l}\text { Low } \\
\text { with } \\
\text { DM }\end{array}$ & Low & & \\
\hline $\begin{array}{c}\text { Quagliata } \\
2014\end{array}$ & Switzerland & $\mathrm{HCC}$ & 52 & qRT-PCR & ROC curve & NA & NA & 32 & NA & NA & 20 & OS & Over 80 \\
\hline $\begin{array}{c}\mathrm{Ge} \\
2015\end{array}$ & China & $\mathrm{HCC}$ & 48 & qRT-PCR & ROC curve & NA & NA & NA & NA & NA & NA & OS & $18(5-72)$ \\
\hline Li 2015 & China & OSA & 68 & qRT-PCR & $\begin{array}{l}\text { Median } \\
\text { value }\end{array}$ & NA & 11 & 34 & NA & 3 & 34 & OS & Over 60 \\
\hline Ren 2015 & China & $\mathrm{CRC}$ & 156 & qRT-PCR & $\begin{array}{l}\text { Median } \\
\text { value }\end{array}$ & 47 & 27 & 77 & 36 & 14 & 79 & OS & $46(33-65)$ \\
\hline Wang 2015 & China & $\mathrm{PC}$ & 144 & qRT-PCR & ROC curve & 75 & NA & 118 & 10 & NA & 26 & OS & Over 60 \\
\hline $\begin{array}{c}\text { Zhang } \\
2015\end{array}$ & China & TSCC & 86 & qRT-PCR & $\begin{array}{l}\text { Median } \\
\text { value }\end{array}$ & 28 & 7 & 44 & 18 & 1 & 42 & OS & $38(23-60)$ \\
\hline Lian 2016 & China & $\mathrm{CRC}$ & 48 & qRT-PCR & $\begin{array}{c}\text { X-tile } \\
\text { algorithm }\end{array}$ & 21 & NA & 32 & 7 & NA & 16 & NA & NA \\
\hline Ye 2016 & China & $\mathrm{GC}$ & 98 & qRT-PCR & $\begin{array}{l}\text { Median } \\
\text { value }\end{array}$ & 39 & NA & 49 & 29 & NA & 49 & OS & Over 60 \\
\hline $\begin{array}{l}\text { Yang } \\
2017\end{array}$ & China & $\mathrm{BC}$ & 100 & qRT-PCR & $\begin{array}{l}\text { Median } \\
\text { value }\end{array}$ & 32 & NA & 50 & 19 & NA & 50 & OS & Over 100 \\
\hline
\end{tabular}

ROC, receiver operating characteristic. NA, not applicable.

\begin{tabular}{|c|c|c|c|}
\hline Study ID & & $\mathrm{HR}(95 \% \mathrm{Cl})$ & Weight $\%$ \\
\hline Quagliata 2014 & $\rightarrow$ & $1.82(0.80,4.15)$ & 8.37 \\
\hline Ge 2015 & $\rightarrow$ & $2.05(1.08,3.92)$ & 13.55 \\
\hline Li 2015 & 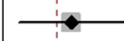 & $2.89(1.27,6.57)$ & 8.37 \\
\hline Ren 2015 & $\rightarrow$ & $2.16(1.32,3.53)$ & 23.61 \\
\hline Wang 2015 & $\longrightarrow$ & $2.59(1.38,4.84)$ & 14.41 \\
\hline Zhang 2015 & $\rightarrow$ & $2.12(1.25,3.59)$ & 20.24 \\
\hline Ye 2016 & $\longrightarrow$ & $2.53(1.18,5.44)$ & 9.70 \\
\hline Yang 2017 & & $7.10(1.17,43.08$ & 1.74 \\
\hline Overall (I-squared $=0.0 \%, \mathrm{p}=0.922)$ & & $2.30(1.81,2.91)$ & 100.00 \\
\hline
\end{tabular}

Figure 2: Forest plot for the relationship between HOTTIP expression and OS.

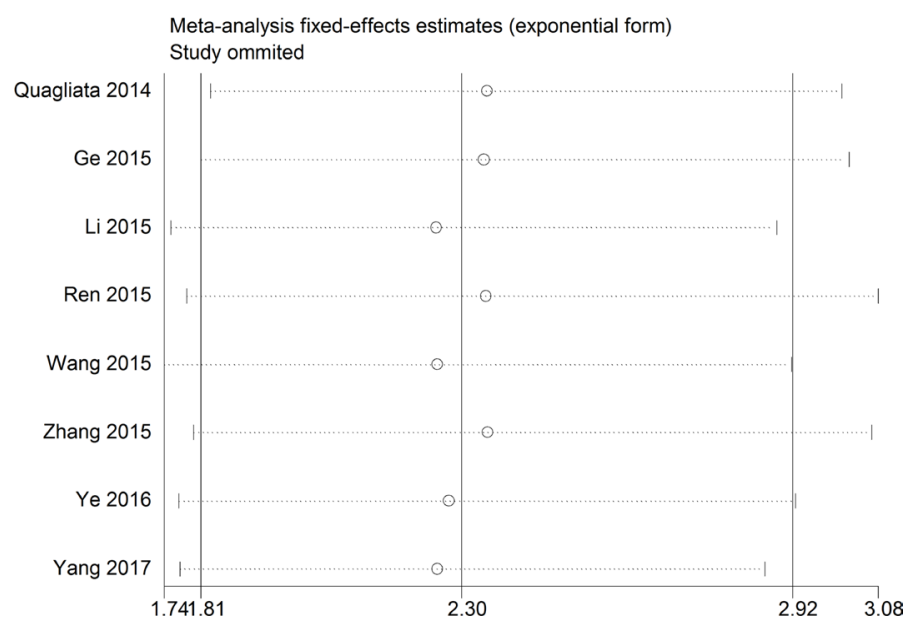

Figure 3: Sensitivity analysis for the meta-analysis. 


\section{Relationship between increased HOTTIP expression and clinicopathological parameters}

Six articles encompassing 632 patients evaluated lymph node metastasis (LNM) according to lncRNA HOTTIP expression. There was no significant heterogeneity among these studies $\left(I^{2}=0 \%, P=0.964\right)$. Subsequently, a fixed-effects model was adopted to analyze the data (Figure 4, Table 2). The odds ratio (OR) of LNM for the high HOTTIP expression group versus the low expression group was 2.40 (95\% CI: $1.70-3.37$, $P<0.001)$.

Three studies described cancer patients with distant metastasis (DM). There was no heterogeneity among these studies $\left(I^{2}=0 \%, P=0.481\right)$. Thus, a fixed-effects model was used to calculate the pooled result (Figure 4, Table 2). The OR of DM was 3.30 for patients with high HOTTIP expression (95\% CI: $1.78-6.12, P<0.001)$. These aggregated results suggested that cancer patients with high HOTTIP expression were more susceptible to LNM and DM than patients with low HOTTIP expression.
In addition, we found that high HOTTIP expression was positively associated with poor tumor differentiation $(\mathrm{OR}=1.55,95 \% \mathrm{CI}: 1.03-2.32, P=0.036)$ and a poor clinical stage $(\mathrm{OR}=3.28,95 \% \mathrm{CI}: 2.22-4.83, P<0.001)$ (Figure 4, Table 2). However, increased HOTTIP expression did not correlate significantly with age or gender (Figure 4, Table 2). Due to insufficient data, we were unable to determine the association between high HOTTIP expression and other clinicopathological parameters.

\section{Publication bias}

We performed Begg's funnel plot analysis to evaluate the publication bias. There was no obvious publication bias affecting the analysis of OS $(P r>|z|=0.458)$, LNM $(\operatorname{Pr}>|z|=0.851)$ or DM $(\operatorname{Pr}>|z|=0.296)$ (Figure 5).

\section{DISCUSSION}

HOTTIP is a 3,764-nucleotide-long lncRNA encoded by a gene at the homeobox A (HOXA) locus [4].

\begin{tabular}{|c|c|c|}
\hline Study ID & OR $(95 \% \mathrm{Cl})$ & Weight $\%$ \\
\hline \multicolumn{3}{|l|}{ Age $(\geq 60$ vs. $<60)$} \\
\hline Ren 2015 & $1.10(0.58,2.08)$ & 35.39 \\
\hline Zhang 2015 & $1.01(0.43,2.36)$ & 20.63 \\
\hline Wang 2015 & $0.89(0.38,2.08)$ & 21.94 \\
\hline Ye 2016 & $0.74(0.30,1.79)$ & 22.04 \\
\hline Subtotal $(I-$ squared $=0.0 \%, P=0.903)$ & $0.95(0.65,1.41)$ & 100.00 \\
\hline \multicolumn{3}{|l|}{ Gender(Male vs. Female) } \\
\hline Quagliata 2014 & $2.65(0.40,17.44)$ & 1.99 \\
\hline Lian 2016 & $0.87(0.24,3.13)$ & 7.68 \\
\hline Li 2016 & $0.70(0.27,1.83)$ & 15.23 \\
\hline Ren 2015 & $0.91(0.47,1.76)$ & 27.94 \\
\hline Wang 2015 & $2.47(1.15,5.31)$ & 12.11 \\
\hline Zhang 2015 & $1.31(0.55,3.12)$ & 13.60 \\
\hline Ye 2016 & $0.72(0.32,1.60)$ & 21.45 \\
\hline Subtotal $(I-$ squared $=21.9 \%, P=0.262)$ & $1.11(0.80,1.55)$ & 100.00 \\
\hline \multicolumn{3}{|l|}{ Clinical stage(III/IV vs. I/II) } \\
\hline Lian 2016 & $4.26(1.19,15.20)$ & 7.89 \\
\hline Yang 2017 & $5.69(2.23,14.53)$ & 13.47 \\
\hline Ye 2016 & $2.81(1.17,6.76)$ & 21.26 \\
\hline $\begin{array}{l}\text { Zhang } 2015 \\
\text { Ren } 2015\end{array}$ & $\begin{array}{l}2.86(1.18,6.89) \\
2.69(1.38,5.26)\end{array}$ & $\begin{array}{l}20.55 \\
36.83\end{array}$ \\
\hline Subtotal $(\mathrm{I}$-squared $=0.0 \%, P=0.730)$ & $3.28(2.22,4.83)$ & 100.00 \\
\hline \multicolumn{3}{|c|}{ Differentiation (Poor vs. Well/moderately) } \\
\hline Lian 2016 & $1.99(0.57,6.96)$ & 8.96 \\
\hline Ye 2016 & $1.79(0.75,4.28)$ & 20.16 \\
\hline Zhang 2015 & $0.64(0.19,2.20)$ & 16.86 \\
\hline Ren 2015 & $1.57(0.80,3.07)$ & 35.95 \\
\hline Wang 2015 & $1.86(0.73,4.77)$ & 18.7 \\
\hline Subtotal $(\mathrm{I}-$-squared $=0.0 \%, P=0.669)$ & $1.55(1.03,2.32)$ & 100.00 \\
\hline \multicolumn{3}{|c|}{ Lymph node metastasis(Yes vs. No) } \\
\hline Ren 2015 & $1.87(0.99,3.54)$ & 32.59 \\
\hline Wang 2015 & $2.79(1.16,6.69)$ & 14.06 \\
\hline Zhang 2015 & $2.33(0.98,5.55)$ & 15.77 \\
\hline Lian 2016 & $2.45(0.72,8.38)$ & 7.55 \\
\hline Ye 2016 & $2.69(1.10,6.61)$ & 13.93 \\
\hline Yang 2017 & $2.90(1.29,6.53)$ & 16.10 \\
\hline Subtotal $(\mathrm{I}-$ squared $=0.0 \%, P=0.964)$ & $2.40(1.70,3.37)$ & 100.00 \\
\hline \multicolumn{3}{|l|}{ Distant metastasis (Yes vs. No) } \\
\hline Li 2015 & $4.94(1.24,19.76)$ & 17.11 \\
\hline Ren 2015 & $2.51(1.19,5.27)$ & 75.64 \\
\hline Zhang 2015 & $-7.76(0.91,66.05)$ & 7.25 \\
\hline Subtotal $(I-$ squared $=0.0 \%, P=0.481)$ & $3.30(1.78,6.12)$ & 100.00 \\
\hline $\mathrm{T}_{.0151}$ & $\underset{66.1}{T}$ & \\
\hline
\end{tabular}

Figure 4: Forest plot for the relationship between HOTTIP expression and clinicopathological parameters. 
Table 2: Meta-analysis results on the association of increased HOTTIP expression with clinicopathological parameters

\begin{tabular}{lcccccc}
\hline \multirow{2}{*}{ Clinicopathological parameter } & $\begin{array}{c}\text { Patient } \\
\text { number }\end{array}$ & OR (95\% CI) & P value & \multicolumn{4}{c}{ Heterogeneity } \\
\cline { 5 - 7 } & 484 & $0.95(0.65-1.41)$ & 0.81 & 0.57 & $0.0 \%$ & 0.902 \\
Age ( $\geq 60$ vs. $<60)$ & 662 & $1.11(0.80-1.55)$ & 0.536 & 7.69 & $21.9 \%$ & 0.261 \\
Gender (Male vs. Female) & 488 & $3.28(2.22-4.83)$ & $<0.001$ & 2.03 & $0.0 \%$ & 0.731 \\
Clinical stage (III/IV vs. I/II) & 532 & $1.55(1.03-2.32)$ & 0.036 & 2.37 & $0.0 \%$ & 0.667 \\
Differentiation (Poor vs. Well/moderately) & 632 & $2.40(1.70-3.37)$ & $<0.001$ & 0.98 & $0.0 \%$ & 0.964 \\
$\begin{array}{l}\text { Lymph node metastasis } \\
\text { (Yes vs. No) }\end{array}$ & 310 & $3.30(1.78-6.12)$ & $<0.001$ & 1.46 & $0.0 \%$ & 0.481 \\
$\begin{array}{l}\text { Distant metastasis } \\
\text { (Yes vs. No) }\end{array}$ & & & & & &
\end{tabular}

HOTTIP recruits histone-modifying enzymes to activate $H O X$ gene transcription and inhibit tumor-suppressor gene expression $[4,18]$. Therefore, HOTTIP has been considered as a carcinogenic factor, and overexpression of HOTTIP has been reported to promote tumor growth $[13,18]$. We conducted this comprehensive metaanalysis to evaluate the relationship of IncRNA HOTTIP expression with prognostic results and clinicopathological parameters in cancer patients.

Nine eligible studies met the selection requirements of this meta-analysis. The data from tumor patients were processed according to OS, age, gender, clinical stage, differentiation, LNM and DM. Our results suggested that cancer patients with high HOTTIP expression in tumor tissues were more likely to exhibit poor tumor differentiation, a poor clinical stage, LNM and DM than patients with low HOTTIP expression. In addition, we found that increased HOTTIP levels were significantly and negatively associated with shorter OS times in tumor patients. Sensitivity analysis indicated that no single study impacted the overall results, suggesting that the pooled results were robust. Furthermore, no obvious publication bias or heterogeneity was observed among our included studies.

Many studies have demonstrated that HOTTIP may be an oncogenic lncRNA. HOTTIP was reported to influence HCC cell proliferation [8]. Knockdown of HOTTIP reduced HOXA13 expression, and knockdown of HOXA13 also reduced HOTTIP expression in HCC-
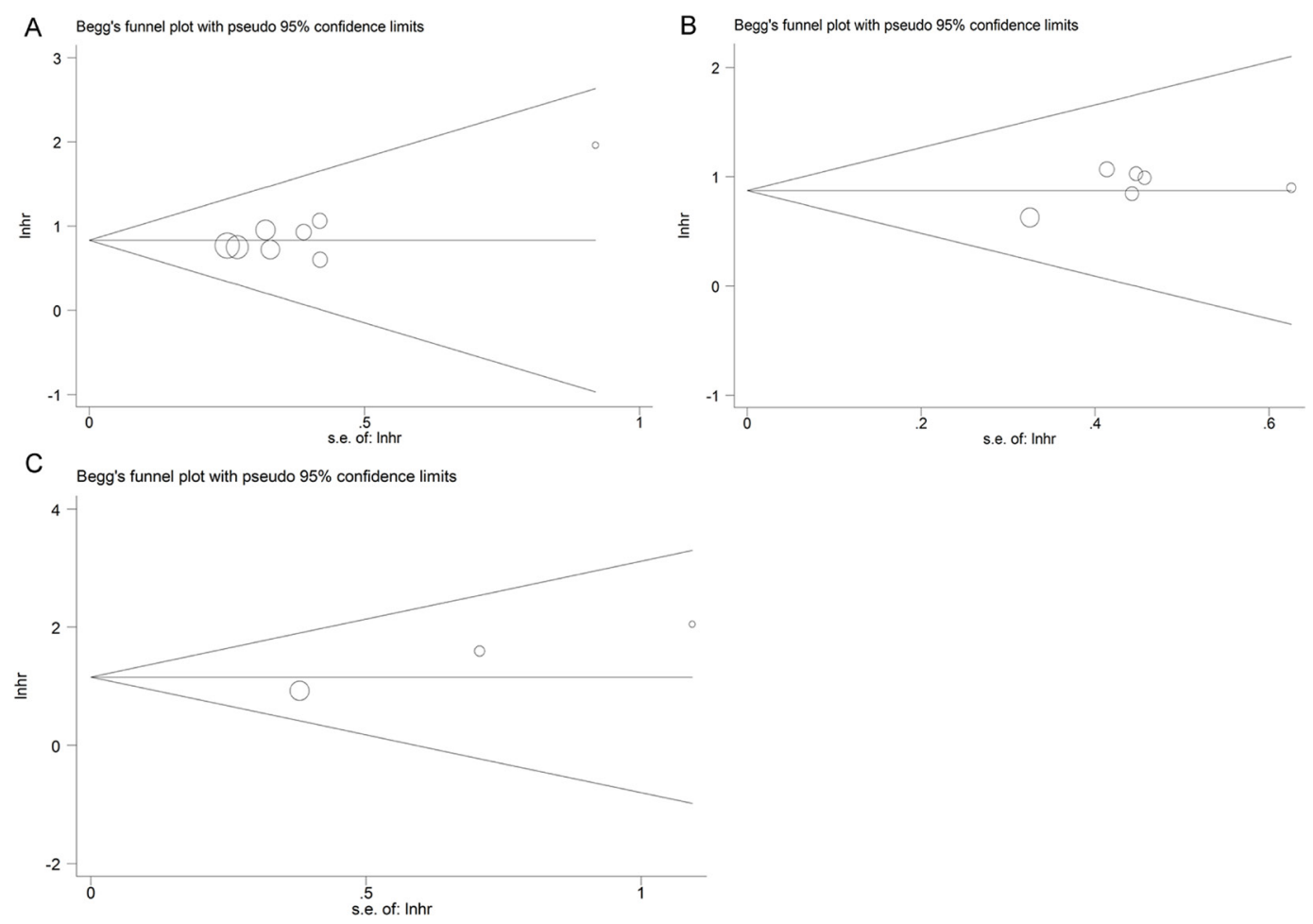

Figure 5: Funnel plot analysis of potential publication bias in the meta-analysis. (A) OS group; (B) LNM group; (C) DM group. 
derived cell lines [8]. Tsang and colleagues [19] found that downregulation of HOTTIP markedly reduced the expression of numerous HOXA genes and weakened liver cancer growth and metastasis both in vivo and in vitro. HOTTIP also was shown to be upregulated in human pancreatic ductal adenocarcinoma tissues and to promote pancreatic ductal adenocarcinoma cell proliferation, migration, invasion and resistance by regulating HOXA13 [20]. However, another study in pancreatic cancer cells demonstrated that HOTTIP did not modulate $H O X A 13$ expression, but did regulate the expression of other HOX genes such as HOXA1, HOXA9, HOXA10, HOXA11 and HOXB2 [21]. In addition, Lian and coworkers [12] found that HOTTIP promoted CRC cell growth by silencing p21 expression. Furthermore, HOTTIP was reported to inhibit cell apoptosis and promote the progression of prostate cancer and lung cancer $[13,22]$. These results may illustrate why high HOTTIP expression was significantly associated with a poor prognosis in cancer patients in this meta-analysis.

There are some limitations that should be noted for the current study. Firstly, most of the included cancer patients were from Chinese populations. Thus, our results need to be confirmed with more clinical data from other ethnic groups. Secondly, some HRs and their corresponding 95\% CIs were extracted from KaplanMeier curves, and may have been less reliable than those obtained directly from articles. Thirdly, the number of original studies included in this meta-analysis was small. Fourthly, studies with positive results are more likely to be published than those with negative results. Thus, as a literature-based analysis, this study may have overestimated the association between high HOTTIP expression and clinical outcomes. Finally, many other factors may also influence OS, such as gender, age and treatment. Thus, the results of our meta-analysis should be confirmed in future studies.

In conclusion, our meta-analysis suggests that the upregulation of HOTTIP is a risk factor for poor clinical outcomes in diverse cancers, and could serve as a potential prognostic biomarker. Nevertheless, given the limitations described above, well-designed studies of particular carcinoma types and large sample sizes are needed to confirm the clinical utility of HOTTIP.

\section{MATERIALS AND METHODS}

\section{Literature search strategy}

We conducted a literature search in the online electronic databases of Embase, Web of Science, PubMed and CNKI (up to January 2, 2017). The search keywords and their combinations were: "HOTTIP OR Homeobox A transcript at the distal tip" AND "cancer OR carcinoma OR tumor OR tumour OR neoplasm". Only English and Chinese articles were included in this study.

\section{Selection and exclusion criteria}

The inclusion criteria of this meta-analysis were: (1) research on the association between HOTTIP and cancer prognosis, (2) division of patients into two groups: high or low HOTTIP expression, and (3) sufficient data for the computation of ORs or HRs with $95 \%$ CIs. The exclusion criteria for our meta-analysis were: (1) duplicate articles, (2) case reports, letters, expert opinions, editorials and reviews, and (3) studies without available data.

\section{Data extraction}

Two investigators (Wei Li and Xinmei Kang) extracted and reviewed the data from the eligible studies independently. Another researcher (Ke Shi) resolved any disagreements. The collected data were as follows: first author's name, publication date, study region, tumor type, tumor stage, detection method for HOTTIP expression, criteria for high HOTTIP expression, sample size, total patient number, number of patients in the high HOTTIP and low HOTTIP groups, number of patients with LNM and $\mathrm{DM}$ in each group, survival analysis, follow-up period, HR and corresponding 95\% CI. If the survival data were not shown directly in the article, Engauge Digitizer v.4.1 software was used to obtain them from the KaplanMeier curve, as previously described [23].

\section{Statistical methods}

STATA 12.0 software (Stata, College Station, Texas) was used to perform all statistical analyses in this study. Patients were separated into the high and low HOTTIP expression groups according to the original published articles. The heterogeneity among the included studies was judged with the $Q$-statistic test and the chi-squared test. A "Begg's funnel plot" was used to determine the potential publication bias. A fixed-effects model was used to analyze the pooled results when the included studies did not exhibit significant heterogeneity $(P>0.1)$; otherwise, a randomeffects model was employed $(P<0.1)$. A sensitivity analysis was conducted to evaluate the robustness of the overall results. All $P$-values were determined with a two-tailed test, and $P<0.05$ was regarded as statistically significant.

\section{ACKNOWLEDGMENTS AND FUNDING}

This work was supported by funding from the Key Program of Hunan Province Science and Technology Hall (2015SK20662).

\section{CONFLICTS OF INTEREST}

The authors have declared that no conflicts of interest exists. 


\section{REFERENCES}

1. Siegel RL, Miller KD, Jemal A. Cancer statistics, 2016. CA Cancer J Clin. 2016; 66:7-30.

2. Chen W, Zheng R, Baade PD, Zhang S, Zeng H, Bray F, Jemal A, Yu XQ, He J. Cancer statistics in China, 2015. CA Cancer J Clin. 2016; 66:115-132.

3. Kapranov P, Cheng J, Dike S, Nix DA, Duttagupta R, Willingham AT, Stadler PF, Hertel J, Hackermüller J, Hofacker IL, Bell I, Cheung E, Drenkow J, et al. RNA maps reveal new RNA classes and a possible function for pervasive transcription. Science. 2007; 316:1484-1488.

4. Wang KC, Yang YW, Liu B, Sanyal A, CorcesZimmerman R, Chen Y, Lajoie BR, Protacio A, Flynn RA, Gupta RA, Wysocka J, Lei M, Dekker J, et al. A long noncoding RNA maintains active chromatin to coordinate homeotic gene expression. Nature. 2011; 472:120-124.

5. Chen LL. Linking Long Noncoding RNA Localization and Function. Trends Biochem Sci. 2016; 41:761-772.

6. Loewer S, Cabili MN, Guttman M, Loh YH, Thomas K, Park IH, Garber M, Curran M, Onder T, Agarwal S, Manos PD, Datta S, Lander ES, et al. Large intergenic non-coding RNARoR modulates reprogramming of human induced pluripotent stem cells. Nat Genet. 2010; 42:1113-1117.

7. Luo Q, Chen Y. Long noncoding RNAs and Alzheimer's disease. Clin Interv Aging. 2016; 11:867-872.

8. Quagliata L, Matter MS, Piscuoglio S, Arabi L, Ruiz C, Procino A, Kovac M, Moretti F, Makowska Z, Boldanova T, Andersen JB, Hämmerle M, Tornillo L, et al. Long noncoding RNA HOTTIP/HOXA13 expression is associated with disease progression and predicts outcome in hepatocellular carcinoma patients. Hepatology. 2014; 59:911-923.

9. Ye H, Liu K, Qian K. Overexpression of long noncoding RNA HOTTIP promotes tumor invasion and predicts poor prognosis in gastric cancer. Onco Targets Ther. 2016; 9:2081-2088

10. Ge Y, Yan X, Jin Y, Yang X, Yu X, Zhou L, Han S, Yuan Q, Yang M. MiRNA-192 and miRNA-204 Directly Suppress lncRNA HOTTIP and Interrupt GLS1-Mediated Glutaminolysis in Hepatocellular Carcinoma. PLoS Genet. 2015; 11:e1005726.

11. Wang Y, Li Z, Zheng S, Zhou Y, Zhao L, Ye H, Zhao X, Gao W, Fu Z, Zhou Q, Liu Y, Chen R. Expression profile of long non-coding RNAs in pancreatic cancer and their clinical significance as biomarkers. Oncotarget. 2015; 6:35684-35698. https://doi.org/10.18632/oncotarget.5533.

12. Lian YF, Ding J, Zhang Z, Shi Y, Zhu Y, Li J, Peng P, Wang J, Fan Y, De W, Wang K. The long noncoding RNA HOXA transcript at the distal tip promotes colorectal cancer growth partially via silencing of p21 expression. Tumour Biol. 2016; 37:7431-7440.
13. Deng HP, Chen L, Fan T, Zhang B, Xu Y, Geng Q. Long non-coding RNA HOTTIP promotes tumor growth and inhibits cell apoptosis in lung cancer. Cell Mol Biol (Noisyle-grand). 2015; 61:34-40.

14. Zhang H, Zhao L, Wang YX, Xi M, Liu SL, Luo LL. Long non-coding RNA HOTTIP is correlated with progression and prognosis in tongue squamous cell carcinoma. Tumour Biol. 2015; 36:8805-8809.

15. Ren YK, Xiao Y, Wan XB, Zhao YZ, Li J, Li Y, Han GS, Chen XB, Zou QY, Wang GC, Lu CM, Xu YC, Wang YC. Association of long non-coding RNA HOTTIP with progression and prognosis in colorectal cancer. Int J Clin Exp Pathol. 2015; 8:11458-11463.

16. Li F, Cao L, Hang D, Wang F, Wang Q. Long non-coding RNA HOTTIP is up-regulated and associated with poor prognosis in patients with osteosarcoma. Int J Clin Exp Pathol. 2015; 8:11414-11420.

17. Yang Y, Qian J, Xiang Y, Chen Y, Qu J. The prognostic value of long noncoding RNA HOTTIP on clinical outcomes in breast cancer. Oncotarget. 2017; 8:6833-6844. https://doi. org/10.18632/oncotarget.14304.

18. Lian Y, Cai Z, Gong H, Xue S, Wu D, Wang K. HOTTIP: a critical oncogenic long non-coding RNA in human cancers. Mol Biosyst. 2016; 12:3247-3253.

19. Tsang FHC, Au SL, Wei L, Fan DN, Lee JM, Wong CC, $\mathrm{Ng}$ IO, Wong CM. Long non-coding RNA HOTTIP is frequently up-regulated in hepatocellular carcinoma and is targeted by tumour suppressive miR-125b. Liver Int. 2015; 35:1597-1606.

20. Li Z, Zhao X, Zhou Y, Liu Y, Zhou Q, Ye H, Wang Y, Zeng J, Song Y, Gao W, Zheng S, Zhuang B, Chen H, et al. The long non-coding RNA HOTTIP promotes progression and gemcitabine resistance by regulating HOXA13 in pancreatic cancer. J Transl Med. 2015; 13:84.

21. Cheng Y, Jutooru I, Chadalapaka G, Christopher Corton J, Safe S. The long non-coding RNA HOTTIP enhances pancreatic cancer cell proliferation, survival and migration. Oncotarget. 2015; 6:10840-10852. https://doi.org/10.18632/ oncotarget. 3450.

22. Zhang SR, Yang JK, Xie JK, Zhao LC. Long noncoding RNA HOTTIP contributes to the progression of prostate cancer by regulating HOXA13. Cellular and molecular biology (Noisy-le-Grand, France). 2016; 62:84-88.

23. Xiao J, Hu CP, He BX, Chen X, Lu XX, Xie MX, Li W, He SY, You SJ, Chen Q. PTEN expression is a prognostic marker for patients with non-small cell lung cancer: a systematic review and meta-analysis of the literature. Oncotarget. 2016; 7:57832-57840. https://doi.org/10.18632/ oncotarget.11068. 